\title{
27-hydroxycholesterol and the expression of three estrogen-sensitive proteins in MCF7 cells
}

\author{
PAMELA CRUZ ${ }^{1}$, MARÍA JOSÉ EPUÑ̃́N ${ }^{1}$, MARÍA EUGENIA RAMÍREZ ${ }^{1}$, \\ CRISTIAN G. TORRES ${ }^{2}$, LUIS E. VALLADARES ${ }^{1}$ and WALTER D. SIERRALTA ${ }^{1}$ \\ ${ }^{1}$ Laboratory of Nutrition and Metabolic Regulation, INTA-University of Chile, Santiago 7830489; \\ ${ }^{2}$ Laboratory of Experimental Medicine, Veterinary Medicine School, \\ University Andrés Bello, Santiago 8370251, Chile
}

Received January 27, 2012; Accepted March 22, 2012

DOI: $10.3892 /$ or.2012.1859

\begin{abstract}
The principal aim of this study was to analyze in estrogen receptor-positive MCF7 cells the response of three estrogen-dependent proteins to 27-hydroxycholesterol (27OHC), a major circulating cholesterol metabolite. Immunofluorescence, immunoblotting and immunogold labelling analyses of MCF7 cells exposed for up to $72 \mathrm{~h}$ to $2 \mathrm{nM}$ estradiol $\left(\mathrm{E}_{2}\right)$ or to $2 \mu \mathrm{M}$ 27OHC demonstrated similar responses in the expression of MnSOD and ER $\beta$ compared to the non-stimulated cells. Thus, the results confirm $27 \mathrm{OHC}$ 's function as a novel selective estrogen receptor modulator (SERM). The epithelial to mesenchymal transition (EMT), observed in MCF7 cells stimulated for longer than $48 \mathrm{~h}$ with $2 \mu \mathrm{M} 27 \mathrm{OHC}$, was accompanied by lower immunoreactive levels of nuclear FOXM1 in comparison to $\mathrm{E}_{2}$-treated cells. The results presented in this study are discussed taking into consideration the relationship of hypercholesterolemia, 27OHC production, ROS synthesis and macrophage infiltration, potentially occurring in obese patients with ER $\alpha$-positive, infiltrated mammary tumors.
\end{abstract}

\section{Introduction}

27-hydroxycholesterol (27OHC), an abundant circulating cholesterol metabolite, is a potent regulator of some mammalian tissues. Few years ago, combined studies by the research groups of Mangelsdorf and MacDonnell demonstrated that $27 \mathrm{OHC}$, locally produced from cholesterol by atheromainfiltrating macrophages, damaged the bordering blood vessels (1). The effects of $27 \mathrm{OHC}$ were exhibited only by cells containing estrogen receptors (ER), therefore the concept of $27 \mathrm{OHC}$ as a novel selective estrogen receptor modulator (SERM) was suggested (2). The same groups reported later on

Correspondence to: Dr Walter D. Sierralta, Laboratorio de Nutrición y Regulación Metabólica, INTA-Universidad de Chile, El Líbano 5524, Santiago 7830489, Chile

E-mail:wsierra@inta.uchile.cl

Key words: 27-hydroxycholesterol, MCF7 cells, mammary cancer, EGFR2/neu, MnSOD, ER $\beta$, FOXM1 the detrimental activity of $27 \mathrm{OHC}$ on bone homeostasis $(3,4)$. The proliferation of various ER-positive mammary cancer cell lines is also affected by $27 \mathrm{OHC}$, as demonstrated by DuSell et al (2) and by us (5). Remarkably, the proliferation rate of nontumorigenic mammary MCF10 cells are not affected by the exposure to micromolar concentrations of $27 \mathrm{OHC}$ (5). Recently, we have demonstrated that the exposure of ER-positive epithelial mammary tumor cells to $2 \mu \mathrm{M} 27 \mathrm{OHC}$ for longer than 48 $\mathrm{h}$ triggers their transition into a mesenchymal phenotype (6).

In diverse cell types, the epithelial-mesenchymal transition (EMT) has been associated with an increase in the production of reactive oxygen species (ROS) (7). In animals, mitochondrion is the main source of ROS and in the organelle $\leq 3 \%$ of the transported electrons can be diverted to the production of superoxide instead of water (8). The regulation of mitochondrial ROS production is not completely understood, although it must be related with the complex modulation of intracellular metabolic processes (9-11). As mentioned above, reactive oxygen species are stimulatory molecules, crucial for the generation of EMT (12). The increased production of ROS in NB4 cells stimulates the translocation of ERK2 into the nucleus, triggering phosphorylation of p53 (13); a consequence of p53 activation is an augmented expression of mitochondrial superoxide dismutase II (MnSOD, also called SOD type II), enzyme with a major role in the protection from oxidative stress (14).

Several studies have demonstrated the presence of ER $\beta$ in various tissues $(15,16)$. Most of the evidence for the presence of this receptor in tissues and cells has been obtained using specific antibody-based assays that, in addition, demonstrate its predominantly mitochondrial localization (17-21). It had been shown that ER $\beta$ regulates the production of energy by mitochondria by controlling the expression of components from the respiratory chain [(MRC) $(22,23)]$. Estrogen-filled receptor promotes the expression of MnSOD, expanding the survival times of these target cells (18). Increased levels of MnSOD protect the cells against oxidative stress and genotoxic injuries by preventing the damage of the mitochondrial (mt) genome and by maintaining the activity of mtDNA polymerase. Ultimately, the enhanced expression of MnSOD defends the cells from genotoxics damaging effects (24).

The expression of ERs in breast cancer cells seems to be related to the function of Forkhead transcription factor FoxM1 
(25). Whereas, the expression of FOXM1 protein and mRNA in breast carcinoma cell lines appears to be regulated by estrogenfilled ER $\alpha$ (26). Recent studies indicate that the expression of the FoxM1 transcription factor is regulated by EGFR2 and it was found in ER $\alpha$-positive breast cancer cell lines that the expression of this protein kinase-receptor is correlated with the expression of FoxM1 (27). FOXM1 regulates the expression of genes controlling the cell cycle at the level of DNA replication and mitosis; an elevated expression of FOXM1 has been reported in numerous ER-positive tumor cells and tissues $(28,29)$.

In the present study we compare the responses of MCF7 cells to $27 \mathrm{OHC}$ and estradiol, emphasizing the analysis of the protein expression of three estrogen-sensitive polypeptides: MnSOD, FoxM1 and ER $\beta$. Stimulation periods of 48 and $72 \mathrm{~h}$ were chosen, including thus the initial phases of EMT in cells exposed to $27 \mathrm{OHC}$ and comparing the responses with those from either non-treated- or estradiol-treated cells.

\section{Materials and methods}

Tissue culture material was obtained from NalgeNunc (Rochester, NY, USA). 27-hydroxycholesterol (C6570-000) was purchased from Steraloids Inc. (Newport, RI, USA). Dulbecco's phosphate buffered saline (DPBS) was from Gibco-Invitrogen Corp. (Carlsbad, CA, USA). Most of the chemicals used here were purchased from Sigma-Aldrich Inc. (St. Louis, MO, USA) or E. Merck KGaA (Darmstadt, Germany).

Antibodies and special probes for cell functionality. Mouse antiactin (sc-8432), anti-ER $\alpha$ (1D5) (sc-56833), anti-EGFR2 (sc-08) and anti- $\beta$ catenin (sc-65482) monoclonal antibodies were obtained from Santa Cruz Biotechnology Inc. (Santa Cruz, CA, USA). Rabbit anti-estrogen receptor $\beta$ (no. 06-629) polyclonal antibody and mouse anti-E-cadherin (MAB3199Z) monoclonal antibody were from Upstate-Chemicon-Millipore (Temecula, CA, USA). Rabbit anti-MnSOD (ab-13533) polyclonal antibody was obtained from Abcam (Cambridge, UK). Mouse anti-FoxM1 (H00002305-M02) monoclonal antibody was from Abnova Inc. (Taipei, Taiwan). FITC-conjugated goat anti-mouse IgG (F0257), peroxidase-conjugated goat anti-rabbit IgG (A6667) and peroxidase-conjugated goat anti-mouse IgG (A9917) were purchased from Sigma-Aldrich. Alexa Fluor-conjugated donkey anti-rabbit IgG (A10040) and MitoTracker ${ }^{\circledR}$ Red CMXRos (M7512) were obtained from Invitrogen/Molecular Probes (Grand Island, NY, USA). The FITC-Annexin flow kit was purchased from BD Biosciences (Bedford, MA, USA). Gold-decorated Fab ${ }_{2}$ fragment $(10 \mathrm{~nm})$ of goat anti-mouse $\operatorname{IgG}(810.188)$ and $\mathrm{Fab}_{2}{ }^{\prime}$ fragment of goat anti-rabbit IgG (810.166) were obtained from Aurion, Wageningen, The Netherlands.

Cells. Estradiol-sensitive MCF7 epithelial cells from human metastatic breast cancer tissue (HTB 22; ATCC, USA), were cultured in DMEM/F12 containing $10 \%$ fetal bovine serum, $100 \mathrm{U} / \mathrm{ml}$ penicillin and $100 \mu \mathrm{g} / \mathrm{ml}$ streptomycin. In the proliferation studies, the cells were transferred $24 \mathrm{~h}$ after seeding to DMEM/F12 containing ITS (insulin, transferrin, selenium), $1 \%$ charcoal/dextran-twice-treated serum (CDTS), 3\% hydroxyethylated starch (HAES), $50 \mathrm{U} / \mathrm{ml}$ penicillin and $50 \mu \mathrm{g} / \mathrm{ml}$ streptomycin. In each of the experiments, the cells were cultured at $37^{\circ} \mathrm{C}$ in a humidified incubator, in a $5 \% \mathrm{CO}_{2}$ atmosphere.
Immunofluorescence studies. MCF7 in medium with $10 \%$ fetal bovine serum $\left(\sim 5,000\right.$ cells $\left./ \mathrm{cm}^{2}\right)$, were seeded on sterile cover glasses hold in P24 plates incubated for $24 \mathrm{~h}$ to allow attachment; subsequently, non-adherent cells and media were removed. The cells were washed twice and incubated for $24 \mathrm{~h}$ with low-serum culture medium; then the medium was then adjusted to either $2 \mu \mathrm{M} 27 \mathrm{OHC}$ or $2 \mathrm{nM} \mathrm{E}_{2}$ and the cells further incubated for up to $72 \mathrm{~h}$, the time required by the cells exposed to $2 \mu \mathrm{M} 27 \mathrm{OHC}$ to frankly display EMT, as checked by immunofluorescent studies using antibodies to E-cadherin, $\beta$-catenin and EGFR2, as described in our previous study (6). At the end of the incubation, the cells were fixed (absolute methanol at $-20^{\circ} \mathrm{C}$ ), rinsed with DPBS and blocked for 30 min with $2 \%$ BSA in DPBS. The samples were then incubated with the primary antibodies for $1 \mathrm{~h}$ at RT. After extensive washes (DPBS containing 2\% BSA), samples were incubated with the appropriate secondary antibody for $1 \mathrm{~h}$ and washed. The samples were mounted with Biomeda Gel/Mount (Foster City, CA, USA) and inspected with a Zeiss Axiophot epifluorescence microscope fitted with a color CCD camera (Kappa GmbH, Goettingen, Germany). In each experiment, the images were obtained under fixed settings of illumination, exposure times and camera gain.

Annexin V/PI labeling. The analyses were carried out using the FITC-Annexin flow kit from BD Biosciences, following the instructions of the manufacturer, as described previously (6).

NBT staining. MCF7 cells on cover glasses were incubated for $1 \mathrm{~h}$ at $37^{\circ} \mathrm{C}$ with a filtered solution of $0.3 \mathrm{mg} / \mathrm{ml} \mathrm{NBT}$ in DPBS. After washing with DPBS, the cells were fixed for $5 \mathrm{~min}$ with absolute methanol and rinsed with water. Finally, the coverslips were mounted with Biomeda Gel/Mount and viewed with differential interference contrast (DIC) with a Zeiss microscope; the images were digitalized with a CCD digital camera.

Western blot analyses. MCF7 cells were grown at $37^{\circ} \mathrm{C}$ and $5 \% \mathrm{CO}_{2}$ in phenol red-free media, containing $10 \%$ fetal bovine serum. For the exposure experiments, the cells were either left untreated (control) or stimulated with $2 \mathrm{nM} 17 \beta$-estradiol $\left(\mathrm{E}_{2}\right)$ or $2 \mu \mathrm{M} 27 \mathrm{OHC}$ in D-Mem/F12 containing $1 \%$ charcoaltreated calf serum. At different times of treatment, cells were lysed to prepare extracts for western blot analyses of the $\mathrm{ER} \alpha, \mathrm{ER} \beta, \mathrm{MnSOD}$, actin, EGFR2, E-cadherin and $\beta$-catenin expression.

Mitotracker CMXRos uptake. The uptake of MitoTracker CMXRos was analyzed following the manufacturer instructions. In brief, cells on the coverslips were incubated for $15 \mathrm{~min}$ with $50 \mathrm{nM}$ of probe, fixed in $3.7 \%$ paraformaldehyde, rinsed with prewarmed DPBS, mounted with Biomeda Gel/Mount, viewed with a Zeiss Axiophot fluorescence microscope and the images documented with a CCD digital camera.

Indirect immunogold labeling. The cells were processed for immunogold labeling according to Sierralta et al (30). In brief, cells exposed to the different treatments, were fixed for $1 \mathrm{~h}$ at $20^{\circ} \mathrm{C}$ with $2 \%$ freshly depolymerized paraformaldehyde $/ 0.05 \%$ glutaraldehyde in $0.1 \mathrm{M}$ phosphate buffer, $\mathrm{pH}$ 7.3. After fixation, the cells were cooled-down, carefully scrapped and thoroughly washed with ice-cold buffer, dehydrated in a graded ethanol 


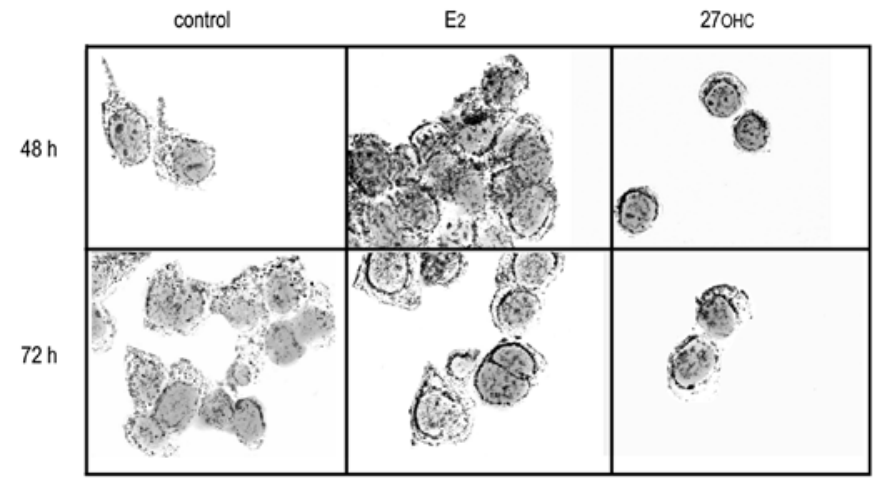

Figure 1. NBT staining in MCF7 cells exposed to estradiol or $27 \mathrm{OHC}$. Representative images from MCF7 cells grown for $24 \mathrm{~h}$ in medium containing $1 \%$ charcoal-treated serum and 3\% HAES, then stimulated for 48 and $72 \mathrm{~h}$ with $2 \mathrm{nME}_{2}$ or $2 \mu \mathrm{M} 27 \mathrm{OHC}$, or maintained in medium alone (control). At the end of the stimulation periods, the cells were incubated at $37^{\circ} \mathrm{C}$ for $1 \mathrm{~h}$ with NBT, then fixed and inspected with a microscope with differential interference contrast.

series and infiltrated at $4^{\circ} \mathrm{C}$ with LR Gold (two changes for $1 \mathrm{~h}$ each and then overnight). The samples were transferred to size-0 gelatine capsules filled with LR Gold containing $0.8 \%$ benzoyl peroxide, placed in a pre-cooled aluminium block and allowed to polymerize for $30 \mathrm{~min}$ at $4^{\circ} \mathrm{C}$ in a desiccator evacuated to $500 \mathrm{~mm} \mathrm{Hg}$. The blocks were cured for 1-2 days af room temperature and then sectioned with a Reichert ultramicrotome using diamond knives. The 70-90-nm thin sections were mounted on pioloform-coated gold grids and immediately incubated. For this purpose, the grids were floated section side-down for $15 \mathrm{~min}$ each at room temperature on droplets of $0.1 \mathrm{M}$ glycin in $20 \mathrm{mM}$ HEPES-buffered saline, pH 7.4 (HBS) and $1 \%$ ovalbumin in HBS, then transferred to droplets of the primary antibody solutions appropriately diluted and left for $2 \mathrm{~h}$ at room temperature followed by $14 \mathrm{~h}$ at $4^{\circ} \mathrm{C}$. After exhaustive washes with HBS to remove any free antibody, the sections were incubated for $1 \mathrm{~h}$ with the appropriated gold-labelled $\mathrm{Fab}_{2}$ 's of the secondary antibodies diluted 1:30 with $1 \%$ ovalbumin in HBS. The specimens were 'jet-washed' with microfiltered buffer and distilled water, mildly postfixed, slightly contrasted with osmium tetroxide and uranyl acetate and viewed with a Philips CM 100 operating at $80 \mathrm{kV}$. Appropriated controls were run to assess the specificity of the localization procedures; with either of these controls, a background of $<1$ gold particle in $200 \mu \mathrm{m}^{2}$ of the sections was observed.

Statistical analyses. Student's t-test was used to evaluate differences between samples and the respective controls. $\mathrm{P}<0.05$ was considered significant. Data were analyzed with Statistica for Windows Software, release 6, Statsoft Inc., USA.

\section{Results}

Non-stimulated MCF7 cells exhibited a basal capacity to build peroxides in the cytoplasm, as detected using the nitroblue tetrazolium test (NBT). Those MCF7 cells exposed to $2 \mathrm{nM} \mathrm{E}_{2}$ or $2 \mu \mathrm{M} 27 \mathrm{OHC}$ displayed increased precipitation of insoluble formazan as compared with the non-stimulated, control cells; the NBT precipitate was associated with particulate elements of the cytoplasm (Fig. 1).

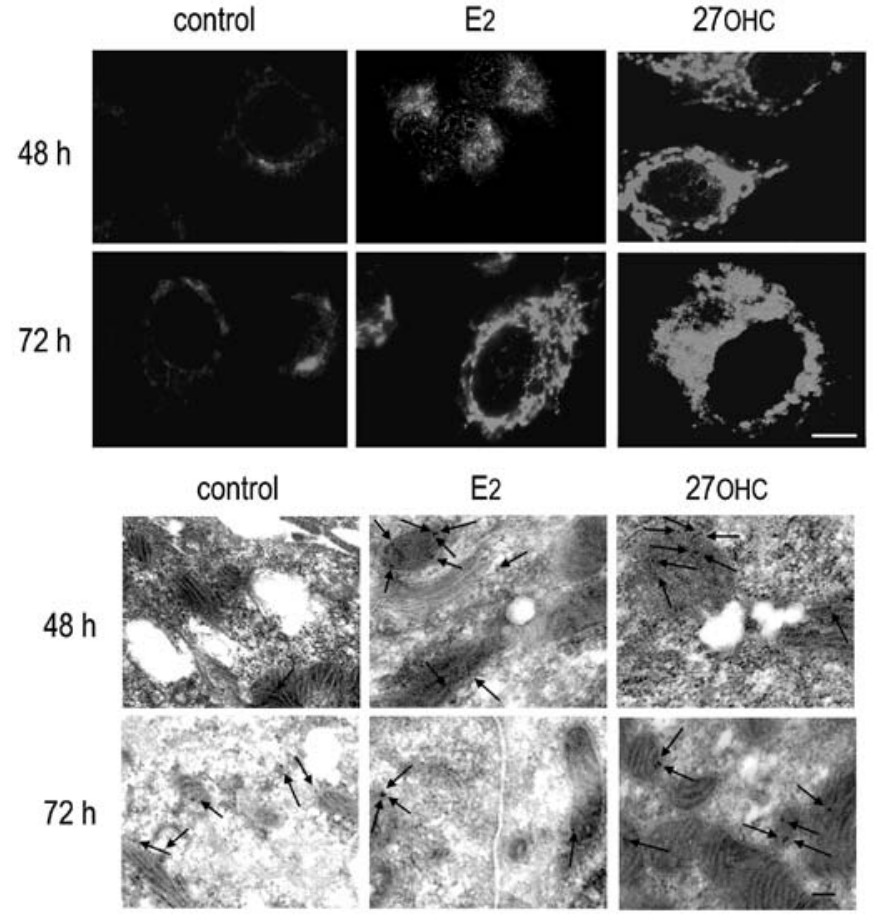

Figure 2. Expression of MnSOD in MCF7 cells. The upper panel depicts representative images from MnSOD expression in cells exposed to estradiol or $27 \mathrm{OHC}$. The images were obtained from cells grown for $24 \mathrm{~h}$ in medium containing $1 \%$ charcoal-treated serum and 3\% HAES, maintained in medium alone (control) or stimulated for 48 and $72 \mathrm{~h}$ with $2 \mathrm{nM} \mathrm{E}_{2}$ or $2 \mu \mathrm{M} 27 \mathrm{OHC}$. Following fixation with cold methanol, the samples were analyzed by indirect immunofluorescence using a specific antiMnSOD antibody followed by Alexa Fluor-conjugated anti-rabbit IgG. Scale bar, $20 \mu \mathrm{m}$. The lower panel displays representative mitochondria-containing areas from post-embedding immunogold labelling of MnSOD in ultrathin sections obtained from MCF7 cells exposed for 48 or $72 \mathrm{~h}$ to $2 \mathrm{nM} \mathrm{E}_{2}, 2 \mu \mathrm{M} 27 \mathrm{OHC}$ or vehicle and fixed, embedded in acrylate resin and the plastic block cut. The ultrathin sections were incubated with anti-MnSOD and a 10-nm gold-decorated anti-rabbit antibody, as described in Materials and methods. The arrows points to the attachment of the $10 \mathrm{~nm}$-large gold particles, tagging the specific occurrence of MnSOD at the surface of the sections. M, mitochondria. Scale bar, $75 \mathrm{~nm}$.

We analyzed for the possible relationship between the augmented production of insoluble formazan and the expression levels of MnSOD in MCF7 cells. Using the specific antibody, immunoreactivity of this dismutase was observed in the mitochondria of MCF7 cells (upper panel, Fig. 2). Following stimulation with either $\mathrm{E}_{2}$ or $27 \mathrm{OHC}$, increases were observed in the expression of MnSOD when compared to non-stimulated cells. The assignation of MnSOD to mitochondria was confirmed by high-resolution, electron microscopy immunogold labeling. The lower panel shown in Fig. 2 depicts representative images of labelled mitochondria in ultrathin sections from non-stimulated and stimulated MCF7 cells embedded in LR-Gold resin. The fluorescence images of MnSOD presence shown in Fig. 2 were analogous to those obtained from the in vivo uptake of Mitotracker CMXRos (Fig. 3).

The immunoreactivity of ER $\beta$ showed essentially a mitochondrial localization in stimulated and non-stimulated cells. Higher expression of ER $\beta$ was detected after 48 and $72 \mathrm{~h}$ estradiol or $27 \mathrm{OHC}$, as shown in the upper panel of Fig. 4. Immunogold-labeling of ultrathin sections with the specific anti-ER $\beta$ antibody demonstrated a predominant mitochondrial residence of ER $\beta$ after either sterol-stimulation. 
Mitotracker

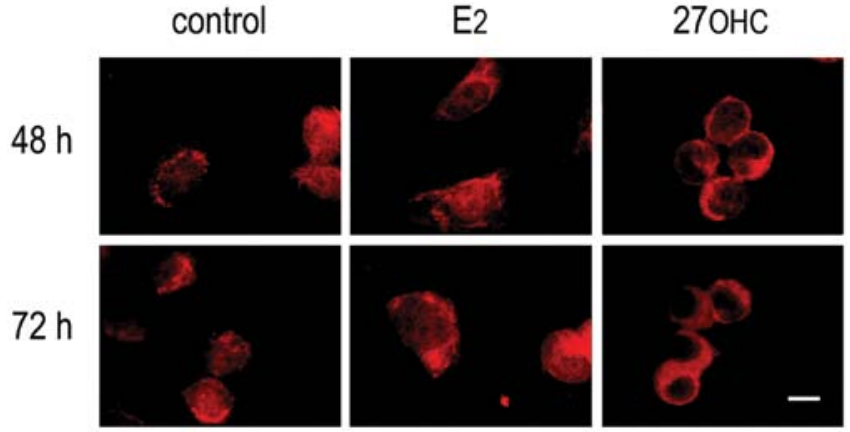

Figure 3. MitoTracker Red CMXRos uptake in MCF7 cells exposed to estradiol or 27OHC. Representative images in MCF7 cells grown for $24 \mathrm{~h}$ in medium containing $1 \%$ charcoal-treated serum and $3 \%$ HAES, then stimulated for 48 and $72 \mathrm{~h}$ with $2 \mathrm{nM} \mathrm{E}_{2}$ or $2 \mu \mathrm{M} 27 \mathrm{OHC}$, or maintained in medium alone (control). Upon completion of the exposure periods, the cells were incubated at $37^{\circ} \mathrm{C}$ for $15 \mathrm{~min}$ with $50 \mathrm{nM}$ MitoTracker Red CMXRos, formaldehyde-fixed and inspected with the fluorescence microscope. Scale bar, $20 \mu \mathrm{m}$. control

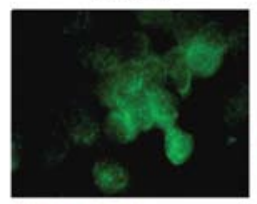

$72 \mathrm{~h}$

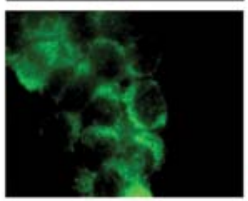

control

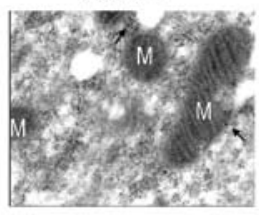

$72 \mathrm{~h}$

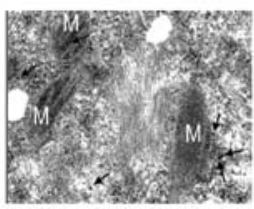

E2
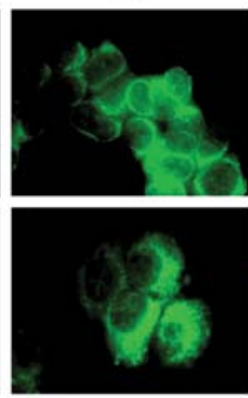

E2
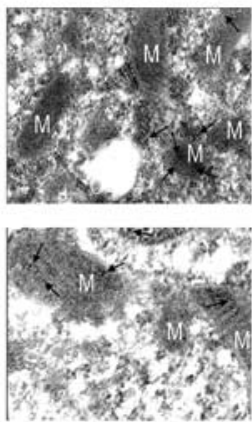

$27 \mathrm{OHC}$

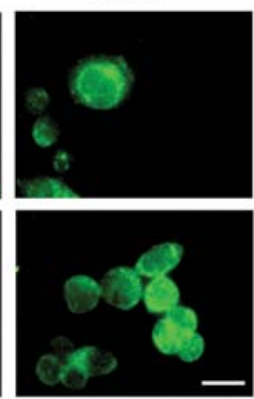

$27 \mathrm{OHC}$
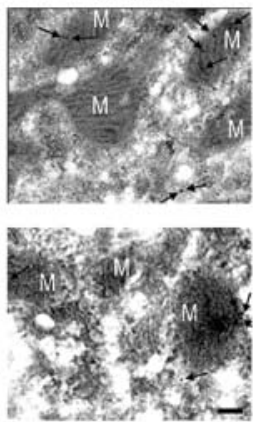

Figure 4. Immunomicroscopical analyses of ER $\beta$ in MCF7 cells exposed to estradiol or $27 \mathrm{OHC}$. The upper panel depicts representative fluorescence images of cells grown for $24 \mathrm{~h}$ in medium containing $1 \%$ charcoal-treated serum and $3 \%$ HAES, then stimulated for 48 and $72 \mathrm{~h}$ with $2 \mathrm{nM} \mathrm{E}_{2}$ or $2 \mu \mathrm{M} 27 \mathrm{OHC}$, or maintained in medium alone (control). After fixation with cold methanol the samples were sequentially incubated with anti-ER $\beta$ antibody and Alexa Fluorlabelled anti-rabbit antibody, as described in Materials and methods. Scale bar, $20 \mu \mathrm{m}$. The lower panel shows representative images from the immunogold labelling of mitochondria-containing areas from MCF7 cells non-stimulated or stimulated for 48 and $72 \mathrm{~h}$ with either $2 \mathrm{nM} \mathrm{E}_{2}$ or $2 \mu \mathrm{M} 27 \mathrm{OHC}$. After stimulation, the cells were fixed, embedded in LR-Gold and the plastic blocks cut. The ultrathin-sections were sequentially incubated with anti-ER $\beta$ and a $10 \mathrm{~nm}$ golddecorated anti-rabbit antibody. Following exhaustive washings, the sections were slightly contrasted and inspected with a transmission electron microscope operating at $80 \mathrm{kV}$. The arrows points to the specific presence of ER $\beta$ in the sections. M, mitochondria; scale bar, $75 \mathrm{~nm}$.

In non-stimulated cells, FoxM1 was customarily detected both in cytoplasm and nucleus by the specific monoclonal

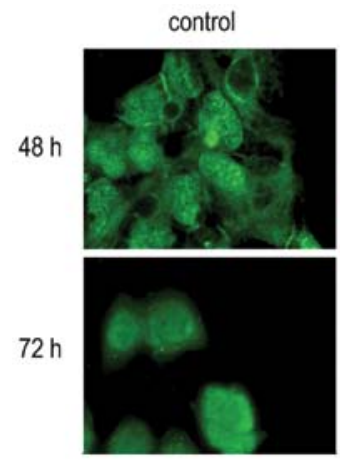

control
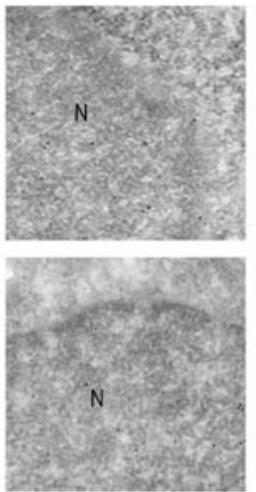

E2

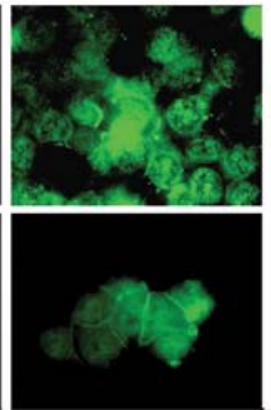

E2
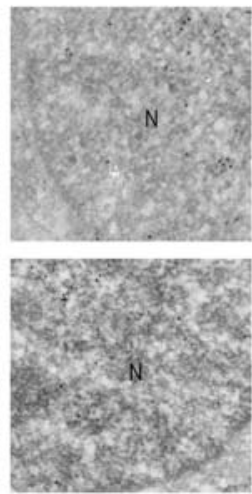

$27 \mathrm{OHC}$

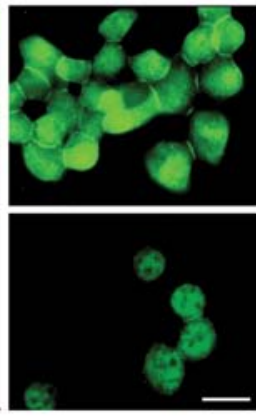

$27 \mathrm{OHC}$
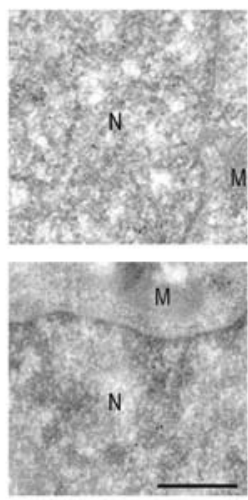

Figure 5. Immunomicroscopical analysis of FOXM1 in MCF7 cells exposed to estradiol or $27 \mathrm{OHC}$. The upper panel depicts representative fluorescence images of FOXM1 in cells grown for $24 \mathrm{~h}$ in medium containing $1 \%$ charcoaltreated serum and $3 \%$ HAES, then stimulated for 48 and $72 \mathrm{~h}$ with $2 \mathrm{nM} \mathrm{E}_{2}$ or $2 \mu \mathrm{M} 27 \mathrm{OHC}$, or maintained in medium alone (control). After fixation with cold methanol the samples were sequentially incubated with anti-FOXM1 antibody and a FITC-labelled anti-mouse antibody, as described in Materials and methods. Scale bar, $25 \mu \mathrm{m}$. The lower panel shows images from FOXM1 immunogold labelling of nucleus-containing areas from MCF7 cells non-stimulated or stimulated for 48 and $72 \mathrm{~h}$ with either $2 \mathrm{nM} \mathrm{E}_{2}$ or $2 \mu \mathrm{M} 27 \mathrm{OHC}$. After stimulation, the cells were fixed, embedded in acrylate and cut. The ultrathin-sections were sequentially incubated with anti-FOXM1 and a 10-nm gold-decorated anti-mouse antibody. Following exhaustive washings, the sections were slightly contrasted and inspected with a transmission electron microscope operating at $80 \mathrm{kV}$. N, nuclei; scale bar, $1 \mu \mathrm{m}$.

antibody. The expression of this potent proliferation controller increased in the nucleus in MCF7 cells exposed for $48 \mathrm{~h}$ to $2 \mathrm{nM}$ estradiol or $2 \mu \mathrm{M} 27 \mathrm{OHC}$; at $72 \mathrm{~h}$ the immunoreactivity remained high in estradiol-treated cells, but declines in the cells treated with $27 \mathrm{OHC}$, as depicted in the upper panel of Fig. 5. This increase in nuclear immunoreactivity was confirmed at ultrastructural level by immunogold labelling, as shown in the lower panel of Fig. 5.

The changes in MnSOD expression in MCF7 cells exposed to estradiol or $27 \mathrm{OHC}$ were analyzed in cell extracts by western blotting; the results confirmed those obtained by indirect immunofluorescence and immunogold labelling studies (Fig. 6).

The changes in the expression of ER $\beta$ after exposure to $E_{2}$ or $27 \mathrm{OHC}$ were analyzed in cell extracts by western blotting. The results obtained were coherent with those obtained by indirect immunofluorescence of whole cells and immunogold labelling analyses of cell sections (Fig. 7). Unfortunately, the specific anti-FoxM1 antibody, used for immunomicroscopy, was non-satisfactory in our hands to detect the protein in western blot analyses, independent on the protocol followed. 
MnSOD

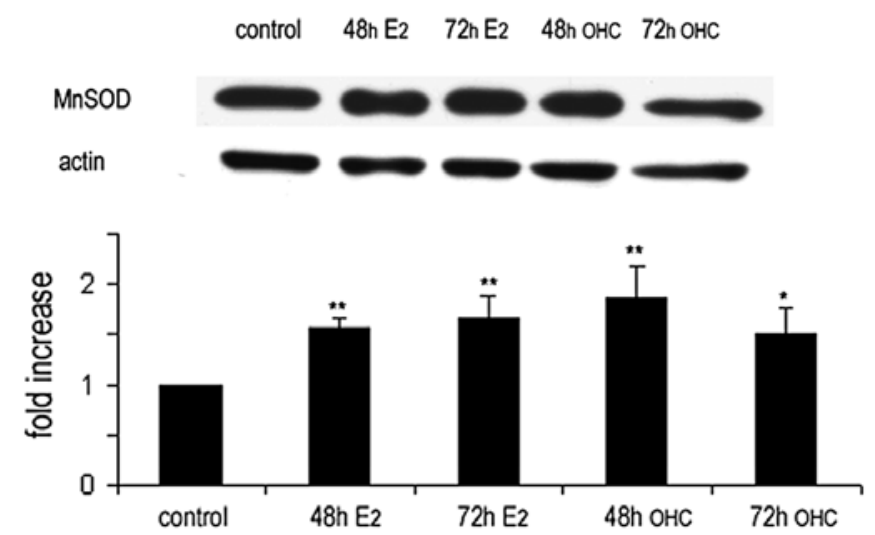

Figure 6. MnSOD in extracts from MCF7 mammary tumor cells. Cells were treated with $2 \mathrm{nME}_{2}$ or $2 \mu \mathrm{M} 27 \mathrm{OHC}$ for the indicated periods; a representative example of MnSOD assessed by western blotting as described in Materials and methods is shown in the upper panel. The histogram below shows the increase of MnSOD in cells treated with estradiol or 27OHC; the value corresponding to the controls was set at 1 . Results are the mean \pm SD from 4 independent experiments; ${ }^{* *} \mathrm{p}<0.01 ;{ }^{*} \mathrm{p}<0.05$ relative to the controls.

\section{ERB}

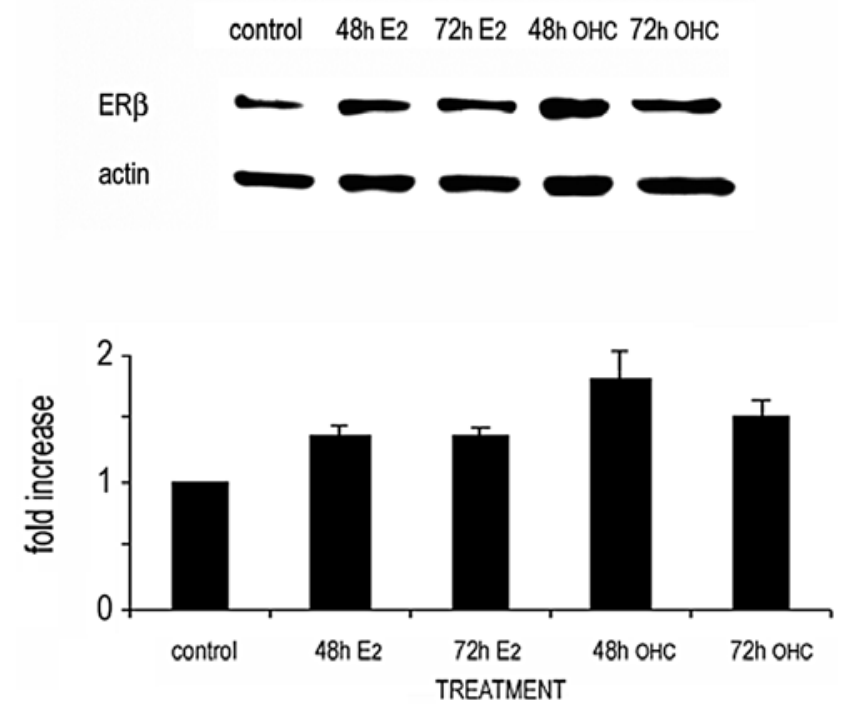

Figure 7. ER $\beta$ in extracts from MCF7 mammary tumor cells. Cells were treated with $2 \mathrm{nME}_{2}$ or $2 \mu \mathrm{M} 27 \mathrm{OHC}$ for the indicated periods; a representative example of ER $\beta$ assessed by western blotting as described in Materials and methods is shown in the upper panel. The histogram below shows the relative increase of $\mathrm{ER} \beta$ in cells treated with estradiol or $27 \mathrm{OHC}$; the value corresponding to the controls was set at 1 . Results are the mean \pm SD from 3 independent experiments; in all cases significant differences $(\mathrm{p}<0.05)$ compared to the controls were observed.

\section{Discussion}

In active cells, tetrazolium salts are reduced in vivo to formazan by the superoxide ion (31); therefore, NBT is widely used as an indicator of mitochondrial metabolism $(11,32)$. Exposing MCF7 cells to either $\mathrm{E}_{2}$ or $27 \mathrm{OHC}$, we observed an increased production of superoxide radical in comparison to the non-treated, control cells. The fluorescence images were comparable to those obtained from the in vivo uptake of Mitotracker CMXRos (Fig. 3). Combined, the results confirm that the treatment with either of these ER-ligands augment the mitochondrial activity, thus increasing ROS production. In parallel to an augmented production of superoxide, we detected the increased expression of MnSOD in stimulated MCF7 cells, suggesting the potential conformation of a defence machinery, probably with the goal to reduce the genotoxic effects from ROS released by the stimulation.

We have demonstrated that an exposure of MCF7 cells to $2 \mu \mathrm{M} 27 \mathrm{OHC}$ for at least $48 \mathrm{~h}$ is adequate for the induction of their epythelial to mesenchymal transition (EMT) (6). The association between an increased production of mitochondrial ROS and induction of EMT in diverse cell types has been reported (7). In the course of EMT, cells acquiring the mesenchymal phenotype exhibit migration and invasion abilities, with new contractile and motile properties. As shown by Giannoni et al, ROS activates the phosphorylation of members from the epidermal growth factor receptor (EGFR) family; this redox-dependent phosphorylation of EGFR activates the protein kinases Akt and ERK causing, among others, the degradation of pro-apoptotic proteins (33). In our earlier report we showed that MCF7 cells undergoing the 27OHC-triggered EMT displayed a persistently activated EGFR2 at the plasma membrane with increased traslocation of pERK into the cell nucleus; interestingly, these cells did not exhibit variations in cell death rates by Annexin V/PI labeling (6). In contrast to the non-genomic mitogenic estradiol effects on MCF7 cells, where just a transient stimulation of EGFR2 is observed (5), the exposure to $27 \mathrm{OHC}$ caused permanent activation of this membrane receptor. As mentioned in our previous study, 27OHC-triggered EGFR2 activation is not related to the secretion of matrix metalloproteinases (MMPs) nor to the trimming and release of HB-EGF (5). Instead, the most important visible signals for the ongoing EMT were the marked evanescence of E-cadherin, the notorious cellular re-allocation of $\beta$-catenin and the permanent activation of EGFR2 (6).

Following the launch of changes in the shape and function of cells experiencing EMT, increases in the cell death rate have been observed (11). As indicated above, we did not detect apoptosis in MCF7 cells following the 27OHC-induced EMT (6). Probably, the increased MnSOD expression would represent a protective cellular response, developed to bypass the toxic effects of the reactive oxygen species generated upon exposure to $27 \mathrm{OHC}$. An example of $27 \mathrm{OHC}$ toxicity is provided by experiments using hippocampus-containing rabbit brain slices, where the exposure to $27 \mathrm{OHC}$ rapidly induced ROS and oxidative stress in nerve cells, eliciting anatomical and physiological alterations comparable to those observed in the brain of Alzheimer disease patients (34).

The changes induced by estradiol and $27 \mathrm{OHC}$ in the proliferation of MCF7 cells and their subsequent EMT, triggered by the oxysterol, are accompanied by an augmented expression of ER $\beta$ in mitochondria. It has been reported that the activity of mitochondrial respiratory complex IV (MRC-IV) in cardiomyocytes tightly depends on mitochondrial ER $\beta$ associated to SERMs; in addition, the filled-ER $\beta$ complex inhibit mitochondrial apoptotic signaling pathways (22). These observations indicate that ER $\beta$ is closely related with the control of mitochondrial activity. Conflicting opinions regarding the expression of ER $\beta$ 
in MCF7 cells are been formulated (35); however, numerous studies have demonstrated that this type of estrogen receptor is present in MCF7 cells $(24,26,36)$. In the studies presented here, we confirmed the presence of this receptor subtype inside mitochondria of MCF7 cells and, in addition, observed changes of its expression following stimulation with estradiol and $27 \mathrm{OHC}$.

Transcription factor Forkhead box M1 (FOXM1) is a key regulator of cell proliferation being overexpressed in many forms of cancers and leading to uncontrolled cell division and genomic instability (37). An increased expression of FOXM1 is associated with the augmented proliferation of many tumor cell lines: FOXM1 regulates the transcription of genes that participate in the control of the cell cycle (38). The antagonist SERM 4-hydroxy-tamoxifen inhibits the expression of FOXM1 in ER-positive but not in ER-negative breast cancer cell lines, supporting the concept of FOXM1 as a key mediator for the activity of SERMs in ER-positive breast cancer cells (39). A positive correlation between FOXM1 expression and EGFR2 status in ER $\alpha$-positive breast cancer cells has been found (28), but more information on the interaction between FOXM1 and EGFR2 is required to discern whether FOXM1 directly activates or not the expression of EGFR2. In our experiments, the MCF7 cells exposed for $72 \mathrm{~h}$ to $27 \mathrm{OHC}$ exhibited a slightly lower expression of FOXM1 as compared to cells exposed to $\mathrm{E}_{2}$ for the same time. Cells treated for $72 \mathrm{~h}$ with $27 \mathrm{OHC}$, display a complete EMT, as judged from the immunolabelling patterns of $\beta$-catenin, E-cadherin and EGFR2 and the absence of proliferation (6). It has been demonstrated in glioma tumorigenesis, that FOXM1 associates with $\beta$-catenin and activate the Wnt pathways (40).

The results presented in this and previous studies $(5,6)$ suggest that in MCF7 cells, $2 \mu \mathrm{M} 27 \mathrm{OHC}$ initially functions as a regular agonist SERM; an exposure to the oxysterol exceeding $48 \mathrm{~h}$ will initiate a non-reversible phenotypical change into a mesenchymal cell type, with increased expression of MnSOD, ER $\beta$ and FOXM1. At the level of these proteins, comparable results were obtained at 48-h exposure between $27 \mathrm{OHC}$ and $\mathrm{E}_{2}$, the most specific ER-ligand. However, we detected lower nuclear levels of FOXM1 after an exposure of $72 \mathrm{~h}$ to $27 \mathrm{OHC}$ and estradiol. The oxisterol-treated cells displayed lower immunoreactivity of the protein, in parallel with an arrested proliferation in the MCF7 cells, transformed by an EMT process by activation of the Wnt signaling pathway.

It is well known that resistance may develop during the treatment of mammary cancer with anti-estrogens and aromatase inhibitors. This may be related to a continual operation of estrogen signaling pathways; a permanently activated path may be the consequence of an association of ERs with endogenous SERMs, such as $27 \mathrm{OHC}$. Through metabolism of profusely available cholesterol, some cells produce and secrete $27 \mathrm{OHC}$ in their neighborhood; the infiltration with macrophages is a negative prognostic indicator in patients with a mammary gland tumor, probably because macrophages vigorously produces $27 \mathrm{OHC}$ (41). It is quite possible that in infiltrated tissues, tumor cells are constantly stimulated by local macrophages transforming cholesterol into $27 \mathrm{OHC}$.

It has been suggested that obesity increases the risk of breast cancer because the high aromatase levels of adipose tissue produce elevated local concentrations of estradiol. However, obesity is associated with hypercholesterolemia and increased levels of circulating $27 \mathrm{OHC}$, therefore, a stimulatory effect of the oxysterol will likely be observed in ER-positive cancer cells from obese patients. Furthermore, the triggering of EMT by $27 \mathrm{OHC}$ in MCF7 cells strengthens the warning about the risks from obesity for breast cancer patients.

\section{Acknowledgements}

This study was supported by Fondecyt Chile, grant no. 1090057.

\section{References}

1. Umetani M, Domoto H, Gormley AK, Yuhanna IS, Cummins CL, Javitt NB, Korach KS, Shaul PW and Mangelsdorf DJ: 27-Hydroxycholesterol is an endogenous SERM that inhibits the cardiovascular effects of estrogens. Nat Med 13: 1185-1192, 2007.

2. DuSell CD, Umetani M, Shaul PW, Mangelsdorf DJ and McDonnell DP: 27-Hydroxycholesterol is an endogenous selective estrogen receptor modulator. Mol Endocrinol 22: 65-77, 2008.

3. DuSell CD, Nelson ER, Wang X, Abdo J, Mödder UI, Umetani M, Gesty-Palmer D, Javitt NB, Khosla S and McDonnell DP: The endogenous selective estrogen receptor modulator 27-hydroxycholesterol is a negative regulator of bone homeostasis. Endocrinology 151: 3675-3685, 2010.

4. Nelson ER, DuSell CD, Wang X, Howe MK, Evans G, Michalek RD, Umetani M, Rathmell JC, Khosla S, Gesty-Palmer D and McDonnell DP: The oxysterol, 27-hydroxycholesterol links cholesterol metabolism to bone homeostasis through its actions on the estrogen and liver X receptors. Endocrinology 152: 4691-4705, 2011.

5. Cruz P, Torres C, Ramírez ME, Epuñán MI, Valladares LE and Sierralta WD: Proliferation of human mammary cancer cells exposed to 27-hydroxycholesterol. Exp Ther Med 1: 531-536, 2010.

6. Torres CG, Ramírez ME, Cruz P, Epuñan MI, Valladares LE and Sierralta WD: 27hydroxycholesterol induces the transition of MCF7 cells into a mesenchymal phenotype. Oncol Rep 26: 389-397, 2011.

7. Zhou G, Dada LA, Wu M, Kelly A, Trejo H, Zhou Q, Varga J and Sznajder JI: Hypoxia-induced alveolar epithelial-mesenchymal transition requires mitochondríal ROS and hypoxia-inducible factor I. Am J Physiol Lung Cell Mol Physiol 297: L1120-L1130, 2009.

8. Boveris A and Chance B: The mitochondrial generation of hydrogen peroxide: general properties and effect of hyperbaric oxygen. Biochem J 134: 707-716, 1973.

9. Nemoto S, Takeda K, Yu Z-X, Ferrans VJ and Finkel T: Role for mitochondrial oxidants as regulators of cellular metabolism. Mol Cell Biol 20: 7311-7318, 2000.

10. Nicholls DG and Budd SU: Mitochondria and neuronal survival. Physiol Rev 80: 315-360, 2000.

11. Werner E and Werb Z: Integrins engage mitochondrial function for signal transduction by a mechanism dependent on Rho GTPases. J Cell Biol 158: 357-368, 2002.

12. Giannoni E, Bianchini F, Calorini L and Chiarugi P: Cancer associated fibroblasts exploit reactive oxygen species through a proinflammatory signature leading to epithelial mesenchymal transition and stemness. Antioxid Redox Signal 14: 2361-2371, 2011.

13. Li Z, Shi K, Guan L, Cao T, Jiang Q, Yang Y and Xu C: ROS leads to MnSOD upregulation through ERK2 translocation and p53 activation in selenite-induced apoptosis of NB4 cells. FEBS Lett 584: 2291-2297, 2010.

14. Bakthavatchalu V,Dey S, Xu Y, Noel T, Jungsuwadee P,Holley AK, Dhar SK, Batinic-Haberle I and St Clair DK: Manganese superoxide dismutase is a mitochondrial fidelity protein that protects Pol $\gamma$ against UV-induced inactivation. Oncogene Sep. 12, 2011 (Epub ahead of print) doi: 10.1038/onc.2011.407.

15. Chen M, Ni J, Chang HC, Lin CY, Muyan M and Yeh S: CCDC62/ ERAP75 functions as a coactivator to enhance estrogen receptor beta-mediated transactivation and target gene expression in prostate cancer cells. Carcinogenesis 30: 841-850, 2009.

16. Monje $\mathrm{P}$ and Boland R: Subcellular distribution of native estrogen receptor alpha and beta isoforms in rabbit uterus and ovary. J Cell Biochem 82: 467-479, 2001. 
17. Fox EM, Davis RJ and Shupnik MA: ER $\beta$ in breast cancer -onlooker, passive player or active protector? Steroids 73: 1039-1051, 2008.

18. Yager ID and Chen JQ: Mitochondrial estrogen receptors-new insights into specific functions. Trends Endocrinol Metab 18 89-91, 2007.

19. Klinge CM: Estrogenic control of mitochondrial function and biogenesis. J Cell Biochem 105: 1342-1351, 2008.

20. Psarra AM and Sekeris CE: Steroid and thyroid hormone receptors in mitochondria. IUBMB Life 60: 210-223, 2008.

21. Simpkins JW, Yang SH, Sarkar SN and Pearce V: Estrogen actions on mitochondria: physiological and pathological implications. Mol Cell Endocrinol 290: 51-59, 2008.

22. Hsieh YC, Yu HP, Suzuki T, Choudhry MA, Schwacha MG Bland KI and Chaudry IH: Upregulation of mitochondrial respiratory complex IV by estrogen receptor-beta is critical for inhibiting mitochondrial apoptotic signaling and restoring cardiac functions following trauma-hemorrhage. J Mol Cell Cardiol 41: 511-521, 2006.

23. Chen JQ, Russo PA, Cooke C, Russo IH and Russo J: ERbeta shifts from mitochondria to nucleus during estrogen-induced neoplastic transformation of human breast epithelial cells and is involved in estrogen-induced synthesis of mitochondrial respiratory chain proteins. Biochim Biophys Acta 1773: 1732-1746, 2007.

24. Bakthavatchalu V, Dey S, Xu Y, Noel T, Jungsuwadee P, Holley AK, Dhar SK, BatinicHaberle I, St Chen JQ, Delannoy M, Cooke C and Yager ID: Mitochondrial localization of ERalpha and ERbeta in human MCF7 cells. Am J Physiol Endocrinol Metab 286: E1011-E1022, 2004.

25. Madureira PA, Varshochi R, Constantinidou D, Francis RE, Coombes RC, Yao KM and Lam EW: The Forkhead box M1 protein regulates the transcription of the estrogen receptor alpha in breast cancer cells. J Biol Chem 281: 25167-25176, 2006.

26. Millour J, Constantinidou D, Stavropoulou AV, Wilson MS Myatt SS, Kwok JM, Pedram A, Razandi M, Wallace DC and Levin ER: Functional estrogen receptors in the mitochondria of breast cancer cells. Mol Biol Cell 17: 2125-2137, 2006.

27. Francis RE, Myatt SS, Krol J, Hartman J, Peck B, McGovern UB, Wang J, Guest SK, Filipovic A, Gojis O, Palmieri C, Peston D, Shousha S, Yu Q, Sicinski P, Coombes RC and Lam EW: FoxM1 is a downstream target and marker of HER2 overexpression in breast cancer. Int J Oncol 35: 57-68, 2009.

28. Bektas N, Haaf A, Veeck J, Wild PI, Lüscher-Firzlaff J, Hartmann A, Knüchel R and Dahl E: Tight correlation between expression of the Forkhead transcription factor FOXMi and HER2 in human breast cancer. BMC Cancer 8: 42, 2008.
29. Sivanandan K, Coombes RC, Medema RH, Hartman J, Lykkesfeldt AE and Lam EW: FOXM1 is a transcriptional target of ERalpha and has a critical role in breast cancer endocrine sensitivity and resistance. Oncogene 29: 2983-2995, 2010.

30. Sierralta WD, Boenig I and Thole HH: Immunogold labelling of estradiol receptor in MCF 7 cells. Cell Tis Res 279: 445-452, 1995.

31. Flohé L and Otting F: Superoxide dismutase assays. Methods Enzymol 105: 93-104, 1984.

32. Powers SK, Lieu FK, Criswell D and Dodd S: Biochemical verification of quantitative histochemical analysis of succinate dehydrogenase activity in skeletal muscle fibres. Histochem J 25: 491-496, 1993.

33. Giannoni E, Buricchi F, Grimaldi G, Parri M, Cialdai F, Taddei ML, Raugei G, Ramponi G and Chiarugi P: Redox regulation of anoikis: reactive oxygen species as essential mediators of cell survival. Cell Death Differ 15: 867-878, 2008.

34. Prasanthi JRP, Larson T, Schommer J and Ghribi O: Silencing GADD153/CHOP gene expression protects against Alzheimer's disease-like pathology induced by 27 -hydroxycholesterol in rabbit hippocampus. PLoS One 6: e26420. doi:10.1371/journal. pone. $0026420,2011$.

35. Nilsson S and Gustafsson JA: Estrogen receptors: therapies targeted to receptor subtypes. Clin Pharmacol Ther 89: 44-55, 2011.

36. Zhao C, Dahlman-Wright K and Gustafsson JA: Estrogen signaling via estrogen receptors. J Biol Chem 285: 39575-39579, 2010.

37. Kwok JM, Peck B, Monteiro U, Schwenen HD, Millour J, Coombes RC, Myatt SS and Lam EW: FOXM1 confers acquired cisplatin resistance in breast cancer cells. Mol Cancer Res 8: 24-34, 2010.

38. Chua PJ, Yip GW and Bay BH: Cell cycle arrest induced by hydrogen peroxide is associated with modulation of oxidative stress related genes in breast cancer cells. Exp Biol Med 234: 1086-1094, 2009

39. Karadedou CT: Regulation of the FOXM1 transcription factor by the estrogen receptor alpha at the protein level in breast cancer. Hippokratia 10: 128-132, 2006.

40. Zhang N, Wei P, Gong A, Chiu WT, Lee HT, Colman H, Huang H, Xue J, Liu M, Wang Y, Sawaya R, Xie K, Yung WK, Medema RH, He X and Huang S: FoxM1 promotes R-catenin nuclear localization and controls Wnt target-gene expression and glioma tumorigenesis. Cancer Cell 20: 427-442, 2011.

41. Steele RJ, Eremin O, Brown M and Hawkins RA: A high macrophage content in human breast cancer is not associated with favourable prognostic factors. Br J Surg 71: 456-458, 1984. 